Original Article

\title{
Sublethal toxicity of carbofuran in cattle egret (Bubulcus ibis coromandus): hematological, biochemical, and histopathological alterations
}

\author{
Toxicidade subletal do carbofurano na garça-vaqueira (Bubulcus ibis coromandus): \\ alterações hematológicas, bioquímicas e histopatológicas
}

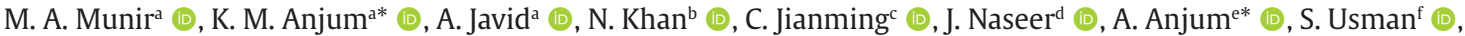

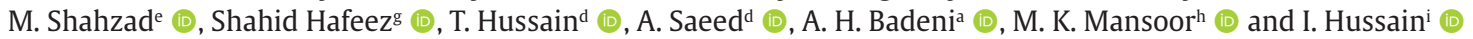 \\ aUniversity of Veterinary and Animal Sciences, Department of Wildlife \& Ecology, Ravi Campus, Pattoki, Pakistan \\ bUniversity of Veterinary and Animal Sciences, Department of Fisheries \& Aquaculture, Ravi Campus, Pattoki, Pakistan \\ 'Minjiang University, Institute of Oceanography, Fuzhou, China \\ dThe Islamia University of Bahawalpur, Department of Forestry, Range and Wildlife Management, Bahawalpur, Pakistan \\ 'The Islamia University of Bahawalpur, Faculty of Veterinary and Animal Sciences, Department of Pathology, Bahawalpur, Pakistan \\ fUniversity of Veterinary and Animal Sciences, Faculty of Veterinary and Animal Sciences, Department of Pathology, Lahore, Pakistan \\ sUniversity of Agriculture Faisalabad, Department of Forestry and Range Management, Faisalabad, Pakistan \\ hThe Islamia University of Bahawalpur, Faculty of Veterinary and Animal Sciences, Department of Microbiology, Bahawalpur, Pakistan \\ 'Bahauddin Zakariya University, Department of Pathobiology, Multan, Pakistan
}

\begin{abstract}
This study was aimed to investigate Carbofuran (CF)-induced pathological changes in cattle egret. Two hundred cattle egrets were reared and equally divided into four groups and given different CF concentrations $(0.03 \mathrm{mg} / \mathrm{L}, 0.02 \mathrm{mg} / \mathrm{L}$, $0.01 \mathrm{mg} / \mathrm{L}$ and $0 \mathrm{mg} / \mathrm{L}$ (control group)). Hematology, serum biochemistry, histopathology, and immunological markers were studied. Our results confirm that CF induces anemic conditions, leukocytosis, elevated liver enzymatic activity, and alterations in renal biomarkers. Moreover, specific microscopic lesions such as multifocal necrosis, pyknotic nuclei, hemorrhages, congestion, and inflammatory cell proliferation were observed in the liver, kidney, spleen, and thymus. These findings suggest that CF can induce harmful effects, so the application of this pesticide in the field must be strictly monitored to mitigate the possibility of exposure to non-target species.
\end{abstract}

Keywords: carbofuran, cattle egret, hematology, serum biochemistry, histopathology.

\begin{abstract}
Resumo
Este estudo teve como objetivo investigar as alterações patológicas induzidas por carbofurano (CF) em garças-vaqueiras. Duzentas dessas garças foram criadas e divididas igualmente em quatro grupos e receberam diferentes concentrações de CF: $0,03 \mathrm{mg} / \mathrm{L} ; 0,02 \mathrm{mg} / \mathrm{L} ; 0,01 \mathrm{mg} / \mathrm{L} ;$ e $0 \mathrm{mg} / \mathrm{L}$ (grupo controle). Foram realizadas análises de hematologia, bioquímica sérica, histopatologia e marcadores imunológicos. Nossos resultados confirmaram que CF induz condições anêmicas, leucocitose, atividade enzimática hepática elevada e alterações nos biomarcadores renais. Além disso, lesões microscópicas específicas, como necrose multifocal, núcleos picnóticos, hemorragias, congestão e proliferação de células inflamatórias, foram observadas no fígado, rim, baço e timo. Esses achados sugerem que o CF pode causar efeitos nocivos, portanto a aplicação desse agrotóxico no campo deve ser rigorosamente monitorada para mitigar a possibilidade de exposição a espécies não alvo.
\end{abstract}

Palavras-chave: carbofurano, garça-vaqueira, hematologia, bioquímica sérica, histopatologia.

\section{Introduction}

For a few decades, extensive use of various pesticides on crops has been reported to control pests and numerous vector-borne diseases. In addition to pests, this practice has a life-threatening effect on non-targeted species such as invertebrates and organisms in the surrounding environment (Ali et al., 2020). Pyrethroids, organochlorines,

organophosphates, and carbamates are the most common insecticides (Saleem et al., 2008). Several organochlorines have been prohibited in agricultural sectors in many countries, yet their illicit manufacturing and use for hygienic purposes cannot be ignored (Eqani et al., 2012). Organophosphate (OP) and carbamate have mostly replaced

*e-mail: ahsan.anjum@iub.edu.pk; khalid.mahmood@uvas.edu.pk

Received: August 5, 2021 - Accepted: September 22, 2021 
organochlorines in Europe, North America, and Australia (Carvalho, 2017). Different pesticides have different harmful effects on animals and humans, and carbamates have comparable toxicity to organophosphates; however, the former has a significantly shorter half-life and is less hazardous. But, carbamate as an organophosphate substitute has resulted in their accumulation in the environment (Ramesh et al., 2015).

Pesticides are the only hazardous substances that are intentionally discharged in a significant amount into the environment. They have side effects on the reproductive system, which leads to breeding failure and stunted growth in the already declining wild birds population (Ibáñez et al., 2010). Furthermore, certain pesticides have a detrimental influence on birds' immunological and neurological systems. Some pesticides may cause eggshell thinning due to low calcium deposition levels, and a few induce genetic mutations (Khan et al., 2014).

Carbofuran (CF) is a systemic insecticide, hence penetrates the plant and poisons the insect when it feeds on it. The extensive use of CF in agriculture results in food, water, and air pollution, which negatively affects human and animal health (Gera et al., 2011). The quantity of CF in environmental samples can be detected with spectrophotometric and chromatographic techniques. In avian species, a value of $0.21 \mathrm{mg} / \mathrm{kg}$ body weight is used for risk assessment analysis in avians (Kamboj et al., 2006).

The avian population is used as an indicator of environmental deterioration, particularly in the United Kingdom, where recreational bird watchers have kept records of avian population count for decades (Fernández et al., 2005). The cattle egret (Bubulcus ibis coromandus) is a medium-sized avian specie that belongs to the Ardeidae family and is mainly found in Pakistan, India, Japan, Australia, Africa, America, and Europe (Sultana et al., 2014). This specie is frequently used to determine the pollution profiles in terrestrial and aquatic environments (Shimshoni et al., 2012).

Apart from these, the toxic effects of $C F$ have also been reported by Barbieri et al. (2019) in Astyanax ribeirae and by Hernández-Moreno et al. (2011) in Dicentrarchus labrax L. in vivo examinations; however, the literature is silent about the lethal effects of CF in any avian species. Therefore, this study was designed to investigate the toxicological effect of CF on hematology, serum biochemistry, histopathology, and immune response of cattle egret.

\section{Materials and Methods}

\subsection{Ethical approval}

The work was approved by the ethical review committee for the use of laboratory animals (ERCULA) of the University of Veterinary and Animal Sciences (UVAS), Lahore, Pakistan (Permit Number: ORIC/DR-1003).

\subsection{Carbofuran}

Carbofuran (granular form) was procured from the local market with the brand name "Furadan 3\%" (FMC United Pvt. Ltd., Pakistan).

\subsection{Study design}

A total of two hundred ( $\mathrm{n}=200$ ) cattle egrets (Bubulcus ibis coromandus) were reared for six months at University of Veterinary and Animal Sciences (UVAS), Ravi Campus, Pattoki, Pakistan. The birds were reared under standard conditions, with free access to food and water. The birds were equally divided into four groups. Group A, B, and C were treated with $\mathrm{CF}$ in drinking water at $0.03 \mathrm{mg} / \mathrm{L}, 0.02 \mathrm{mg} / \mathrm{L}$, and 0.01 $\mathrm{mg} / \mathrm{L}$, respectively (Otieno et al., 2010), while group D was kept as control. At the end of the trial, ten birds from each group were randomly selected, and the blood samples were taken from the wing vein. Half of the blood was subjected to hematological analysis, while the remaining blood was used to separate serum for ELISA and serum biochemical examinations. The same birds were sacrificed by cervical dislocation to collect the tissue samples (liver, kidney, spleen, thymus) for histopathological studies (Sultan et al., 2021).

\subsection{Parameters studies}

\subsubsection{Hematological parameters}

The blood samples collected in ethylenediaminetetraacetic acid (EDTA) containing vacutainers were subjected to hematological analysis, including total erythrocytes count (TEC), total leukocytes count (TLC), differential leukocyte count (DLC), packed cell volume (PCV), hemoglobin concentration (Hb), mean corpuscular volume (MCV), mean corpuscular hemoglobin $(\mathrm{MCH})$, and mean corpuscular hemoglobin concentrations (MCHC) following the protocol as mentioned by Sultan et al. (2021).

\subsubsection{Serum biochemistry profile}

The serum samples were used to determine the alanine aminotransferase (ALT), aspartate aminotransferase (AST), alkaline phosphatase (ALP), creatinine, and urea using the commercially available kits (Roche Diagnostics, Switzerland) as described by Sultan et al. (2017).

\subsubsection{Immunological parameters}

The serum samples were subjected to measure the serum interferon-gamma (IFN- $\gamma$ ) and interleukin-2 (IL-2) level through commercially available ELISA kits (CUSABIO, USA) as described by Tohidi et al. (2012).

\subsubsection{Histopathological examinations}

The tissue samples were fixed in $10 \%$ neutral buffered formalin followed by hydration, dehydration (ascending order of ethanol), clearing with xylene, paraffin wax embedding, and sectioning off ( $4 \mu \mathrm{m})$ with a microtome (SLEE, Germany). Paraffin tissue sections were then deparaffinized using xylene and hydrated in descending concentrations of alcohol. The sections were stained with hematoxylin and eosin ( $\mathrm{H} \& \mathrm{E}$ ) dye, and slides were observed under a light microscope (Olympus, Japan) according to the protocol as described by Sharaf et al. (2021).

\subsection{Statistical analysis}

The data of the above experiments were subjected to factorial statistical analysis using ANOVA, and the mean 
values of different groups were compared by Tukey's multiple comparison test using IBM SPSS version 26.0 software. Results were assumed as statistically significant, considering the $\mathrm{P}$-value $(\mathrm{P}<0.05)$.

\section{Results and Discussion}

\subsection{Hematological parameters}

The studied hematological parameters are shown in Table 1. A pattern of significantly low values of RBC count, PCV, Hb, MCV, MCH, MCHC, and lymphocytes (\%) was observed in $\mathrm{CF}$ exposed groups $\mathrm{A}, \mathrm{B}$, and $\mathrm{C}$ compared to control. A decrease in these markers indicates anemia, which might be due to the negative impact of CF on bone marrow, which resulted in an impaired hemopoietic system associated with reduced cell production. Similar results of decreased hematological parameters have previously been reported by Elkomy et al. (2014) in chickens, Gupta (1994) in albino mice, Adhikari et al. (2004) and Ramesh et al. (2015) in fish. Leukocyte count, heterophils (\%), monocytes (\%), eosinophils (\%), and basophils (\%) of groups A, B, and $\mathrm{C}$ (CF exposed) were significantly high compared to the control. An increase in leukocyte count may be due to stress exhibited by cattle egret after CF administration. Similarly, leukocytosis, heterophilia, eosinophilia, basophilia, and monocytosis were reported in African catfish (Clarias gariepinus) exposed to CF (Harabawy and Ibrahim, 2014). The increased leucocyte count may be attributed to general immune response and inflammatory conditions (Dick and Dixon, 1985; Singh and Srivastava, 2010).

\subsection{Serum biochemical parameters}

Concerning the serum biochemistry analysis, a significant increase in ALT, AST, ALP, creatinine, and urea were found in a dose-dependent pattern in CF-exposed cattle egret compared to the control group (Table 2). Faisal et al. (2008) found that liver injury may cause elevated enzymatic activity (AST and ALT) in birds. This finding strongly suggests that $\mathrm{CF}$ has a deleterious impact on the structure and function of the liver, as evidenced by microscopic lesions in the liver of $\mathrm{CF}$ exposed cattle egret. Furthermore, degenerative changes in hepatocytes may have caused blabbing of ALT outside the cells resulting in high blood ALT levels (Sultan et al., 2017). Similarly, high levels of creatinine and urea are the markers of kidney damage, as noticed in this experiment, indicating the nephrotoxic repercussions of CF. The microscopic lesions can also justify the nephrotoxic impact of $\mathrm{CF}$ in the kidneys. Moreover, Kaur et al. (2012) reported the nephrotoxic effects in rats intoxicated with CF, which is in accordance with our results.

\subsection{Immunological parameters}

Regarding the immune response analysis, a significant decrease in IFN- $\gamma$ and IL- 2 was noted in CF exposed cattle egret compared to the control group (Table 3). T-lymphocytes are important for cell-mediated immunity because they generate IFN- $\gamma$ and IL-2, required for maturation and differentiation of cytotoxic T cells (Peace et al., 2019). IFN- $\gamma$ can also trigger the production of other cytokines, hence contributing to cell-mediated immunity (Haq et al., 2011). Moreover, Casale et al. (1993) reported CF as a potential inhibitor of serine hydrolasedependent immunological activities, such as IL-2 signaling, which ultimately results in $\mathrm{T}$ cell proliferation suppression. CF produced abnormalities in IL-2 synthesis and splenocyte responsiveness to IL-2, leading to T-cell proliferation inhibition. Also, CF substantially reduced the synthesis of

Table 1. Comparison of hematological parameters of carbofuran exposed and non-exposed cattle egret (mean \pm SD).

\begin{tabular}{|c|c|c|c|c|c|}
\hline \multirow{2}{*}{ Parameters } & \multicolumn{4}{|c|}{ Groups } & \multirow{2}{*}{ P-Value $(P<0.05)$} \\
\hline & A & B & C & D & \\
\hline $\begin{array}{l}\text { RBC count } \\
\left(\times 10^{6} / \mathrm{mm}^{3}\right)\end{array}$ & $2.56 \pm 0.06^{\mathrm{a}}$ & $2.61 \pm 0.09^{\mathrm{ab}}$ & $2.65 \pm 0.07^{\mathrm{b}}$ & $2.83 \pm 0.04^{c}$ & $<0.0001$ \\
\hline $\operatorname{PCV}(\%)$ & $38.18 \pm 0.10^{\mathrm{a}}$ & $38.20 \pm 0.11^{\mathrm{ab}}$ & $38.24 \pm 0.11^{\mathrm{b}}$ & $39.51 \pm 0.44^{c}$ & $<0.0001$ \\
\hline $\mathrm{Hb}(\mathrm{g} / \mathrm{L})$ & $8.80 \pm 0.96^{\mathrm{a}}$ & $9.23 \pm 0.72^{b}$ & $9.58 \pm 0.15^{c}$ & $10.83 \pm 1.33^{d}$ & $<0.0001$ \\
\hline $\operatorname{MCV}(\mathrm{fL})$ & $159.94 \pm 0.24^{\mathrm{a}}$ & $160.02 \pm 0.22^{\mathrm{ab}}$ & $160.07 \pm 0.26^{b}$ & $160.82 \pm 0.05^{c}$ & $<0.0001$ \\
\hline $\mathrm{MCH}(\mathrm{pg})$ & $29.97 \pm 0.36^{a}$ & $30.12 \pm 0.21^{\mathrm{ab}}$ & $30.20 \pm 0.23^{b}$ & $30.91 \pm 0.06^{c}$ & $<0.0001$ \\
\hline $\mathrm{MCHC}(\mathrm{g} / \mathrm{dL})$ & $24.20 \pm 0.04^{\mathrm{a}}$ & $24.39 \pm 0.10^{\mathrm{b}}$ & $24.48 \pm 0.07^{c}$ & $24.99 \pm 0.07^{\mathrm{d}}$ & $<0.0001$ \\
\hline $\begin{array}{l}\text { Leukocytes } \\
\left(\times 10^{9} / \mathrm{L}\right)\end{array}$ & $1.05 \pm 0.05^{c}$ & $0.99 \pm 0.18^{\mathrm{b}}$ & $0.90 \pm 0.10^{\mathrm{b}}$ & $0.76 \pm 0.12^{\mathrm{a}}$ & $<0.0001$ \\
\hline Heterophils (\%) & $50.74 \pm 0.15^{\mathrm{d}}$ & $48.65 \pm 0.15^{c}$ & $45.32 \pm 0.13^{b}$ & $43.02 \pm 0.19^{a}$ & $<0.0001$ \\
\hline Lymphocytes (\%) & $41.82 \pm 0.07^{a}$ & $43.80 \pm 0.09^{\mathrm{b}}$ & $45.83 \pm 0.06^{c}$ & $48.74 \pm 0.55^{d}$ & $<0.0001$ \\
\hline Monocytes (\%) & $4.29 \pm 0.02^{\mathrm{d}}$ & $4.26 \pm 0.01^{c}$ & $4.23 \pm 0.01^{\mathrm{b}}$ & $4.21 \pm 0.04^{\mathrm{a}}$ & $<0.0001$ \\
\hline Eosinophils (\%) & $3.60 \pm 0.01^{\mathrm{d}}$ & $3.55 \pm 0.01^{c}$ & $3.53 \pm 0.01^{\mathrm{b}}$ & $3.50 \pm 0.01^{\mathrm{a}}$ & $<0.0001$ \\
\hline Basophils (\%) & $1.94 \pm 0.09^{d}$ & $1.81 \pm 0.07^{c}$ & $1.68 \pm 0.07^{b}$ & $1.32 \pm 0.01^{\mathrm{a}}$ & $<0.0001$ \\
\hline
\end{tabular}

Within a row superscript ${ }^{(\mathrm{a}, \mathrm{b}, \mathrm{c}, \mathrm{d})}$ represent significantly different $(\mathrm{P}<0.05)$ values of each parameter. Description of groups: (A)Carbofuran@0.03 mg/L; (B) Carbofuran@0.02 mg/L; (C) Carbofuran@0.01 mg/L; (D) Control. 
Table 2. Comparison of serum biochemical parameters of carbofuran exposed and non-exposed cattle egret (mean \pm SD).

\begin{tabular}{cccccc}
\hline \multirow{2}{*}{ Parameters } & \multicolumn{3}{c}{ Groups } & \multirow{2}{*}{ P-Value (P<0.05) } \\
\cline { 2 - 5 } & A & B & C & D & $<0.0001$ \\
\hline ALT (IU/L) & $30.37 \pm 0.34^{\mathrm{d}}$ & $28.00 \pm 0.17^{\mathrm{c}}$ & $25.89 \pm 0.12^{\mathrm{b}}$ & $9.02 \pm 0.31^{\mathrm{a}}$ & $<0.0001$ \\
AST (IU/L) & $125.12 \pm 0.46^{\mathrm{d}}$ & $114.84 \pm 0.42^{\mathrm{c}}$ & $96.18 \pm 0.42^{\mathrm{b}}$ & $51.91 \pm 0.38^{\mathrm{a}}$ & $<0.0001$ \\
ALP (IU/L) & $209.74 \pm 0.67^{\mathrm{d}}$ & $201.35 \pm 0.39^{\mathrm{c}}$ & $196.08 \pm 0.75^{\mathrm{b}}$ & $71.18 \pm 0.88^{\mathrm{a}}$ & $<0.0001$ \\
Creatinine (mg/dL) & $0.63 \pm 0.01^{\mathrm{d}}$ & $0.60 \pm 0.01^{\mathrm{c}}$ & $0.57 \pm 0.01^{\mathrm{b}}$ & $0.41 \pm 0.01^{\mathrm{a}}$ & $<0.0001$ \\
Urea (mg/dL) & $4.18 \pm 0.01^{\mathrm{d}}$ & $4.11 \pm 0.01^{\mathrm{c}}$ & $4.02 \pm 0.01^{\mathrm{b}}$ & $3.12 \pm 0.01^{\mathrm{a}}$ & \\
\hline
\end{tabular}

Within a row superscript ${ }^{(\mathrm{a}, \mathrm{b}, \mathrm{c}, \mathrm{d})}$ represent significantly different $(\mathrm{P}<0.05)$ values of each parameter. Description of groups: (A) Carbofuran@0.03 mg/L; (B) Carbofuran@0.02 mg/L; (C) Carbofuran@0.01 mg/L; (D) Control.

Table 3. Comparison of immunological parameters of carbofuran exposed and non-exposed cattle egret (mean \pm SD).

\begin{tabular}{cccccc}
\hline \multirow{2}{*}{ Parameters } & \multicolumn{3}{c}{ Groups } & \multirow{2}{*}{ P-Value (P<0.05) } \\
\cline { 2 - 5 } & A & B & C & D & \\
\hline IFN- $\gamma(\mathrm{pg} / \mathrm{mL})$ & $24.73 \pm 1.08^{\mathrm{a}}$ & $26.53 \pm 1.22^{\mathrm{b}}$ & $27.42 \pm 1.51^{\mathrm{c}}$ & $33.82 \pm 1.11^{\mathrm{d}}$ & $<0.0001$ \\
$\mathrm{IL}-2(\mathrm{pg} / \mathrm{mL})$ & $21.30 \pm 0.38^{\mathrm{a}}$ & $23.35 \pm 0.73^{\mathrm{b}}$ & $25.12 \pm 0.56^{\mathrm{c}}$ & $28.06 \pm 0.66^{\mathrm{d}}$ & $<0.0001$ \\
\hline
\end{tabular}

Within a row superscript ${ }^{(a, b, c, d)}$ represent significantly different $(P<0.05)$ values of each parameter. Description of groups: (A) Carbofuran@0.03 mg/L; (B) Carbofuran@0.02 mg/L; (C) Carbofuran@0.01 mg/L; (D) Control.

Concanavalin A-induced production of IFN- $\gamma$ (Jeon et al., 2001), which agrees with our findings.

\subsection{Histopathological examinations}

Histopathological examination revealed anomalies in the liver, kidney, spleen, and thymus in a dose-dependent pattern of CF administration trials. The liver of the control group was normal with intact parenchyma and wellarranged hepatic cords and central veins. The cytosol of hepatocytes showed no abnormality (Figure 1d). Mild hydropic changes in cytosol along with pyknotic nuclei in the hepatocytes were observed in group C (Figure 1c). Mild to moderate congestion and coagulative necrosis of hepatocytes with diminished sinusoidal spaces due to cellular swelling was noticed in group A and B. Along with this, inflammatory cells aggregation was also seen in the perivascular area of central veins (Figure 1a, 1b). Up till now the most of the histopathological work related to $\mathrm{CF}$ intoxication is reported in Labeo rohita (Sarkar et al., 2005), African catfish (Hamed and Osman, 2017), Mus musculus (Astuti et al., 2019), and rats (Brkić et al., 2008), which showed the similar microscopic anomalies as elucidated in this study, however, there is no evidence of comparable findings in cattle egret in literature.

The renal parenchyma of the control group was normal with intact renal corpuscle containing glomerulus along with Bowman's capsule and renal tubules in the cortex and medullary region (Figure $1 \mathrm{~h}$ ). Mild hemorrhages and necrosis were observed in tubular epithelial cells of group C (Figure 1g). Mild to moderate necrosis and pyknotic nuclei were seen in renal tubules of group $B$ (Figure 1f). A similar pattern of anomalies was noticed in group A. However, the kidney of group A showed severe hemorrhages, necrosis along with occlusion of fluid in renal tubules lumen, and accumulation of inflammatory cells in renal spaces resulted in interstitial nephritis (Figure 1e). Similar renal abnormalities were also reported in albino mice (Islam et al., 2014), tilapia fish (Hamed et al., 2021), broiler chicks (Ali et al., 2020), and rats (Datta et al., 2021), while the literature is lacking in evidence about $\mathrm{CF}$ intoxication in cattle egret.

The parenchyma of the thymus was normal in the control group with no microscopic lesions in the cortex, medulla, and corticomedullary region (Figure 11). However, progressive atrophy of thymic lobules was observed in groups A, B, and C, in a dose-dependent pattern of CF administration (Figure 1i, 1j, 1k). Focally extensive necrosis along with pyknotic nuclear debris was noted in the multiple necrotic foci in CF-treated groups. Also, extensive hemorrhages, focal areas of fibrosis, and localized inflammation were seen in groups A and B. The microscopic architecture of the spleen of the control group was normal with marked white and red pulp (Figure 1p). CF administration induced disseminated multifocal necrosis, splenic congestion, and extensive lymphocytolysis in bursal dependent lymphoid follicles of spleen of groups A, B, and C (Figure 1m, 1n, 10). A similar pattern of microscopic abnormalities in immune organs exposed to CF was observed in mice (Handy et al., 2002), broiler chicks (Garg et al., 2004), and ewes (Rawlings et al., 1998), but the literature on CF poisoning in cattle egret is lacking.

\section{Conclusions}

It has been proven that $\mathrm{CF}$ administration could lead to hemato-biochemical, histopathological, and immunopathological alterations in cattle egret in a 

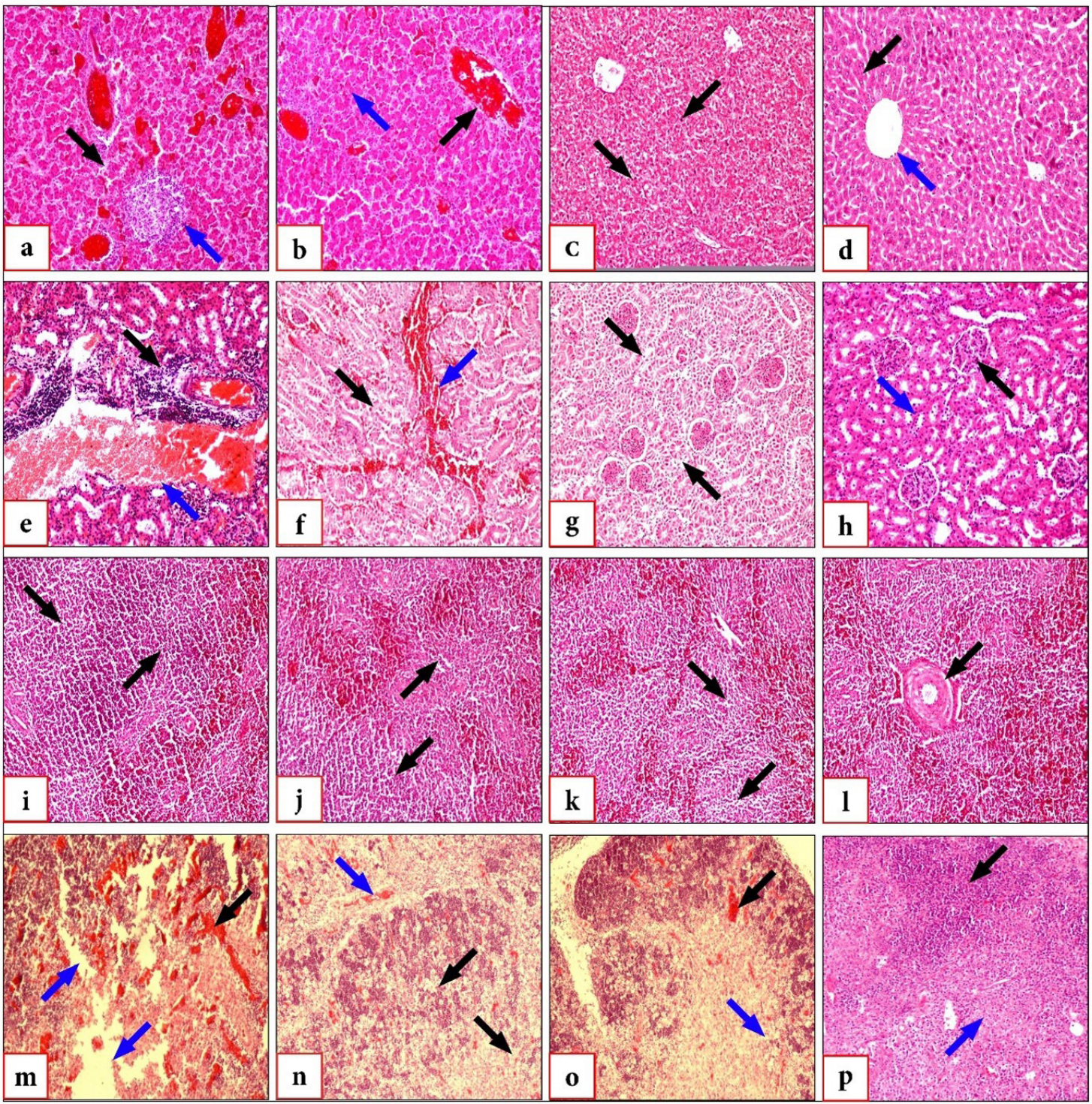

Figure 1. Photomicrographs of liver (a, b, c, d), kidney (e, f, g, h), spleen (i, j, k, l) and thymus (m, n, o, p) of group A (Carbofuran 0.03 mg/L), group B (Carbofuran $0.02 \mathrm{mg} / \mathrm{L}$ ), group C (Carbofuran $0.01 \mathrm{mg} / \mathrm{L}$ ) and group D (control) (H\&E stain, 10X). (a) Inflammatory cells infiltration in perivascular area (blue arrow) and coagulative necrosis of hepatocytes (black arrow) in group A; (b) Cellular swelling resulted in narrowing sinusoidal spaces (blue arrow) and moderate hepatic congestion (black arrow) in group B; (c) Necrotic hepatocytes with pyknotic nuclei (black arrow) in group C; (d) Normal central vein (blue arrow) and normal hepatic cords (black arrow) in group D; (e) Severe hemorrhages (blue arrow) and inflammatory cells aggregation in interstitial spaces resulted in interstitial nephritis (black arrow) in group A; (f) Severe renal congestion (blue arrow) and renal tubular epithelial cells necrosis with pyknotic nuclei (black arrow) in group B; (g) Mild degenerative changes in renal tubular epithelial cells (black arrow) in group C; (h) Normal renal tubules (blue arrow) and renal corpuscles (black arrow) in group D; (i) Extensive lymphocytolysis in bursal dependent lymphoid follicles of spleen (black arrow) in group A; (j) Moderate splenic congestion (blue arrow) and necrotic immune cells in white pulp of spleen (black arrow) in group B; (k) Mild necrosis of splenocytes (black arrow) in group C; (l) Normal white pulp and red pulp having normal central artery (black arrow) in group D; (m) Multiple necrotic foci (blue arrow) and extensive hemorrhages (black arrow) in group A; (n) Moderate hemorrhages (blue arrow) and necrotic thymocytes (black arrow) in group B; (o) Mild hemorrhages (blue arrow) and necrotic thymocytes (black arrow) in group C; (p) Normal cortex (black arrow) and medulla (blue arrow) of thymus of group D.

dose-dependent pattern. However, the actual mode of action of $\mathrm{CF}$ in cattle egret is enigmatic. According to our findings, systemic insecticides like CF may have harmful impacts on humans and the environment, especially at high concentrations. Quantity and modes of application of this pesticide in the field must be strictly monitored to mitigate the possibility of exposure to non-target species, including human beings. This can be accomplished by raising public awareness about the deleterious effects of CF through public health education. 


\section{Acknowledgements}

This work was partially supported by the Higher Education Commission (HEC), Government of Pakistan through the program National Research Program for Universities (No. 20-4258/NRPU/R\&D/HEC/14/1081).

\section{References}

ADHIKARI, S., SARKAR, B., CHATTERJEE, A., MAHAPATRA, C.T. and AYYAPPAN, S., 2004. Effects of cypermethrin and carbofuran on certain hematological parameters and prediction of their recovery in a freshwater teleost, Labeo rohita (Hamilton). Ecotoxicology and Environmental Safety, vol. 58, no. 2, pp. 220-226. http://dx.doi.org/10.1016/j.ecoenv.2003.12.003. PMid:15157576.

ALI, A., KHATOON, A., UL ABIDIN, Z., HUSSAIN, S., SALEEMI, M.K., ABBAS, R.Z., JAVED, M.T., GUL, S.T. and RIZVI, F., 2020. The adverse effects of carbofuran are efficiently counteracted by the supplementation of star anise (Illicium verum) in broiler chicks. Toxin Reviews vol. 40, no. 4, pp. 692-701. http://dx.doi. org/10.1080/15569543.2020.1749082.

ASTUTI, S.D., VICTORY, V.S., MAHMUD, A.F., PUTRA, A.P. and WINARNI, D., 2019. The effects of laser diode treatment on liver dysfunction of Mus musculus due to carbofuran exposure: an in vivo study.Journal of Advanced Veterinary and Animal Research, vol. 6, no. 4, pp. 499-505. http://dx.doi.org/10.5455/javar.2019. f374. PMid:31819878.

BARBIERI, E., FERRARINI, A.M.T., REZENDE, K.F.O., MARTINEZ, D.S.T. and ALVES, O.L., 2019. Effects of multiwalled carbon nanotubes and carbofuran on metabolism in Astyanax ribeirae, a native species. Fish Physiology and Biochemistry, vol. 45, no. 1, pp. 417-426. http://dx.doi.org/10.1007/s10695-018-0573-2. PMid:30276578.

BRKIĆ, D.V., VITOROVIĆ, S.L., GAŠIĆ, S.M. and NEŠKOVIĆ, N.K., 2008. Carbofuran in water: subchronic toxicity to rats. Environmental Toxicology and Pharmacology, vol. 25, no. 3, pp. 334-341. http:// dx.doi.org/10.1016/j.etap.2007.11.002. PMid:21783871.

CARVALHO, F., 2017. Pesticides, environment, and food safety. Food and Energy Security, vol. 6, no. 2, pp. 48-60. http://dx.doi. org/10.1002/fes3.108.

CASALE, G.P., VENNERSTROM, J.L., BAVARI, S. and WANG, T.L., 1993. Inhibition of interleukin 2 driven proliferation of mouse CTLL2 cells, by selected carbamate and organophosphate insecticides and congeners of carbaryl. Immunopharmacology and Immunotoxicology, vol. 15, no. 2-3, pp. 199-215. http:// dx.doi.org/10.3109/08923979309025994. PMid:8349949.

DATTA, S., MANNA, K., DEY, S., DHAR, P. and GHOSH, M., 2021. Protective role of Ipomoea aquatica Forsk. crude extract on rat tissues in the presence of acephate and carbofuran by histopathology and cytometric determination. Indian Journal of Experimental Biology, vol. 59, no. 2, pp. 118-124. PMid:4644870.

DICK, P.T. and DIXON, D.G., 1985. Changes in circulating blood cell levels of rainbow trout, Salmo gairdneri Richardson, following acute and chronic exposure to copper. Journal of Fish Biology, vol. 26, no. 4, pp. 475-481. http://dx.doi. org/10.1111/j.1095-8649.1985.tb04287.x.

ELKOMY, A.E., ABD EL HAMID, A.E.H.E., MAHMOUD, S.S., DEKINESH, S.I. and AHMED, M.A., 2014. Medicago sativa seed as a natural source of isoflavones to counteract the toxicity of contaminated broiler rations. Global Journal of Pharmacology, vol. 8, pp. 437-443.

EQANI, S.A.-M.-A.-S., MALIK, R.N., ALAMDAR, A. and FAHEEM, H., 2012. Status of organochlorine contaminants in the different environmental compartments of Pakistan: a review on occurrence and levels. Bulletin of Environmental Contamination and Toxicology, vol. 88, no. 3, pp. 303-310. http://dx.doi. org/10.1007/s00128-011-0496-4. PMid:22173707.

FAISAL, B.A., ABDEL-FATTAH, S.A., EL-HOMMOSANY, Y.M., ABDELGAWAD, N.M. and ALI, M.F.M., 2008. Immunocompetence, hepatic heat shock protein 70 and physiological responses to feed restriction and heat stress in two body weight lines of Japanese quail. International Journal of Poultry Science, vol. 7, no. 2, pp. 174-183. http://dx.doi.org/10.3923/ijps.2008.174.183.

FERNÁNDEZ, J.M., SELMA, M.A.E., AYMERICH, F.R., SÁEZ, M.T.P. and FRUCTUOSO, M.F.C., 2005. Aquatic birds as bioindicators of trophic changes and ecosystem deterioration in the Mar Menor lagoon (SE Spain). Hydrobiologia, vol. 550, no. 1, pp. 221-235. http://dx.doi.org/10.1007/s10750-005-4382-0.

GARG, U.K., PAL, A.K., JHA, G.J. and JADHAO, S.B., 2004. Haematobiochemical and immuno-pathophysiological effects of chronic toxicity with synthetic pyrethroid, organophosphate and chlorinated pesticides in broiler chicks. International Immunopharmacology, vol. 4, no. 13, pp. 1709-1722. http:// dx.doi.org/10.1016/j.intimp.2004.08.002. PMid:15454122.

GERA, N., KIRAN, R. and MAHMOOD, A., 2011. Carbofuran administration induces genotoxic effects in epithelial cells across crypt-villus axis in rat intestine. Pesticide Biochemistry and Physiology, vol. 100, no. 3, pp. 280-283. http://dx.doi. org/10.1016/j.pestbp.2011.04.013.

GUPTA, C., 1994. Carbofuran toxicity. Journal of Toxicology and Environmental Health, vol. 43, no. 4, pp. 383-418. http://dx.doi. org/10.1080/15287399409531931. PMid:7990167.

HAMED, H.S. and OSMAN, A.G.M., 2017. Modulatory effect of lycopene against carbofuran toxicity in African catfish, Clarias gariepinus. Fish Physiology and Biochemistry, vol. 43, no. 6, pp. 1721-1731. http://dx.doi.org/10.1007/s10695-017-0404-x. PMid:28721486.

HAMED, H.S., ISMAL, S.M. and FAGGIO, C., 2021. Effect of allicin on antioxidant defense system, and immune response after carbofuran exposure in Nile tilapia, Oreochromis niloticus. Comparative Biochemistry and Physiology. Toxicology $\mathcal{E}^{\circ}$ Pharmacology : CBP, vol. 240, pp. 108919. http://dx.doi. org/10.1016/j.cbpc.2020.108919. PMid:33122135.

HANDY, R.D., ABD-EL SAMEI, H.A., BAYOMY, M.F.F., MAHRAN, A.M., ABDEEN, A.M. and EL-ELAIMY, E.A., 2002. Chronic diazinon exposure: pathologies of spleen, thymus, blood cells, and lymph nodes are modulated by dietary protein or lipid in the mouse. Toxicology, vol.172, no. 1, pp. 13-34. http://dx.doi.org/10.1016/ S0300-483X(01)00575-3. PMid:11844612.

HAQ K., ELAWADLI, I., PARVIZI, P., MALLICK, A.I., BEHBOUDI, S. and SHARIF, S., 2011. Interferon- $\gamma$ influences immunity elicited by vaccines against very virulent Marek's disease virus. Antiviral Research, vol. 90, no. 3, pp. 218-226. http://dx.doi.org/10.1016/j. antiviral.2011.04.001. PMid:21501630.

HARABAWY, A.S.A. and IBRAHIM, A.T.A., 2014. Sublethal toxicity of carbofuran pesticide on the African catfish Clarias gariepinus (Burchell, 1822): Hematological, biochemical and cytogenetic response. Ecotoxicology and Environmental Safety, vol. 103, no. 1, pp. 61-67. http://dx.doi.org/10.1016/j.ecoenv.2013.09.022. PMid:24461394.

HERNÁNDEZ-MORENO, D., PÉREZ-LÓPEZ, M., SOLER, F., GRAVATO, C. and GUILHERMINO, L., 2011. Effects of carbofuran on the sea bass (Dicentrarchus labrax L.): study of biomarkers and behaviour alterations. Ecotoxicology and Environmental Safety, vol. 74, no. 7, pp. 1905-1912. http://dx.doi.org/10.1016/j.ecoenv.2011.07.016. PMid:21864905. 
IBÁÑEZ, C., CURCÓ, A., RIERA, X., RIPOLL, I. and SÁNCHEZ, C., 2010. Influence on birds of rice field management practices during the growing season: a review and an experiment. SSRN Electronic Journal, vol. 33, no. 1, pp. 167-180.

ISLAM, M.S., MOHANTA, M.K., SAHA, A.K., MONDOL, A., HOQUE, M. and ROY, A.K., 2014. Carbofuran-induced alterations in body morphometrics and histopathology of liver and kidneys in the Swiss albino mice Mus Musculus L. Experimental Brain Research, vol. 2, no. 9, pp. 308-322.

JEON, S.D., LIM, J.S. and MOON, C.K., 2001. Carbofuran suppresses T-cell-mediated immune responses by the suppression of T-cell responsiveness, the differential inhibition of cytokine production, and NO production in macrophages. Toxicology Letters, vol. 119, no. 2, pp. 143-155. http://dx.doi.org/10.1016/ S0378-4274(00)00307-6. PMid: 11311576.

KAMBOJ, A., KIRAN, R. and SANDHIR, R., 2006. Carbofuran-induced neurochemical and neurobehavioral alterations in rats: attenuation by $\mathrm{N}$-acetylcysteine. Experimental Brain Research, vol. 170, no. 4, pp. 567-575. http://dx.doi.org/10.1007/s00221005-0241-5. PMid:16307259.

KAUR, B., KHERA, A. and SANDHIR, R., 2012. Attenuation of cellular antioxidant defense mechanisms in kidney of rats intoxicated with carbofuran. Journal of Biochemical and Molecular Toxicology, vol. 26, no. 10, pp. 393-398. http://dx.doi.org/10.1002/jbt.21433. PMid:22807346.

KHAN, M., MOHAMMAD, A., AHAD, K., KATSOYIANNIS, A., MALIK, S.A., ABDULLAHA, M., RASHID, A., FASOLA, M., HUSSAIN, A., BOKHARI, H. and EQANI, S.A.M.A.S., 2014. Cattle egrets as a biosentinels of persistent organic pollutants exposure. Environmental Geochemistry and Health, vol. 36, no. 3, pp. 375-384. http://dx.doi.org/10.1007/s10653-013-9556-5. PMid:24046197.

OTIENO, P.O., LALAH, J.O., VIRANI, M., JONDIKO, I.O. and SCHRAMM, K.W., 2010. Carbofuran and its toxic metabolites provide forensic evidence for Furadan exposure in vultures (Gyps africanus) in Kenya. Bulletin of Environmental Contamination and Toxicology, vol. 84, no. 5, pp. 536-544. http://dx.doi.org/10.1007/s00128010-9956-5. PMid:20372877.

PEACE, A.C., KUMAR, S., WILLS, R., MACKIN, A., HOH, C.M. and ARCHER, T., 2019. Pharmacodynamic evaluation of the effects of oral melatonin on expression of the T-cell cytokines interleukin-2 and interferon gamma in the dog. Journal of Veterinary Pharmacology and Therapeutics, vol. 42, no. 3, pp. 278-284. http://dx.doi.org/10.1111/jvp.12749. PMid:30680749.

RAMESH, M., NARMADHA, S. and POOPAL, R.K., 2015. Toxicity of furadan (carbofuran 3\% g) in Cyprinus carpio: Haematological, biochemical and enzymological alterations and recovery response. Beni-Suef University Journal of Basic and Applied Sciences, vol. 4, no. 4, pp. 314-326. http://dx.doi.org/10.1016/j. bjbas.2015.11.008.

RAWLINGS, N., COOK, S. and WALDBILLIG, D., 1998. Effects of the pesticides carbofuran, chlorpyrifos, dimethoate, lindane, triallate, trifluralin, 2,4-D, and pentachlorophenol on the metabolic endocrine and reproductive endocrine system in ewes.
Journal of Toxicology and Environmental Health. Part A., vol. 54, no. 1, pp. 21-36. http://dx.doi.org/10.1080/009841098159006. PMid:9588346.

SALEEM, M., AHMAD, M., AHMAD, M., ASLAM, M. and SAYYED, A., 2008. Resistance to selected organochlorin, organophosphate, carbamate and pyrethroid, in Spodoptera Litura (Lepidoptera: Noctuidae) From Pakistan. Journal of Economic Entomology, vol. 101, no. 5, pp. 1667-1675. http://dx.doi.org/10.1603/00220493(2008)101[1667:RTSOOC]2.0.CO;2. PMid:18950050.

SARKAR, B., CHATTERJEE, A., ADHIKARI, S. and AYYAPPAN, S., 2005. Carbofuran- and cypermethrin-induced histopathological alterations in the liver of Labeo rohita (Hamilton) and its recovery. Journal of Applied Ichthyology, vol. 21, no. 2, pp. 131-135. http:// dx.doi.org/10.1111/j.1439-0426.2004.00590.x.

SHARAF, S., KHAN, M.U., ASLAM, A., RABBANI, M., SHARF, A., IJAZ, M., ANJUM, A. and HUSSAIN, N., 2021. Toxico-pathological effects of heavy metals from industrial drainage wastewater on vital organs of small ruminants in Lahore. Environmental Science and Pollution Research International, vol. 28, no. 3, pp. 3533-3543. http://dx.doi.org/10.1007/s11356-020-10051-4. PMid:32918689.

SHIMSHONI, J., EVGENY, E., LUBLIN, A., CUNEAH, O., KING, R., HOROWITZ, I. and SHLOSBERG, A., 2012. Determination of brain cholinesterase activity in normal and pesticide exposed wild birds in Israel. Israel Journal of Veterinary Medicine, vol. 67, no. 4, pp. 214-219.

SINGH, N.N. and SRIVASTAVA, A.K., 2010. Haematological parameters as bioindicators of insecticide exposure in teleosts. Ecotoxicology, vol. 19, no. 5, pp. 838-854. http://dx.doi.org/10.1007/s10646010-0465-4. PMid:20177774.

SULTAN, R., ASLAM, A., SALEEM, G., ANJUM, A., KRULL, W., KUMOSANI, T. and BARBOUR, E.K., 2017. Studies on performance, immunity, and safety of broilers vaccinated with killed H9N2 vaccine and supplemented with essential oils of Mentofin ${ }^{\circledR}$ in drinking water. International Journal of Applied Research in Veterinary Medicine, vol. 15, no. 2, pp. 67-74.

SULTAN, R., ASLAM, A., TIPU, M., REHMAN, H., USMAN, S., ANJUM, A., IMRAN, M.S., USMAN, M. and IQBAL, M.Z., 2021. Pathology and molecular characterization of Eimeria tenella isolated from clinically infected broiler chickens in district Lahore, Pakistan. Pakistan Journal of Zoology, vol. 54, no. 1, pp. 1-9. http://dx.doi. org/10.17582/journal.pjz/20200622030642.

SULTANA, J., SYED, J.H., MAHMOOD, A., ALI, U., REHMAN, M.Y.A., MALIK, R.N., LI, J. and ZHANG, G., 2014. Investigation of organochlorine pesticides from the Indus Basin, Pakistan: sources, air-soil exchange fluxes and risk assessment. The Science of the Total Environment, vol. 497-498, pp. 113-122. http:// dx.doi.org/10.1016/j.scitotenv.2014.07.066. PMid:25127446.

TOHIDI, R., IDRIS, I., PANANDAM, J.M. and BEJO, M.H., 2012. The effects of polymorphisms in IL- 2 , IFN- $\gamma$, TGF- $\beta 2$, IgL, TLR-4, MD-2, and iNOS genes on resistance to Salmonella Enteritidis in indigenous chickens. Avian Pathology, vol. 41, no. 6, pp. 605-612. http://dx.doi.org/10.1080/03079457.2012.739680. PMid:23237374. 